\title{
Comment on Point:Counterpoint "Positive effects of intermittent hypoxia (live high:train low) on exercise performance are/are not mediated primarily by augmented red cell volume"
}

Jose A L Calbet, Robert Boushel and Carsten Lundby

Journal of Applied Physiology 100:749-, 2006. doi:10.1152/japplphysiol.01119.2005

You might find this additional information useful...

This article cites 5 articles, 4 of which you can access free at: http://jap.physiology.org/cgi/content/full/100/2/749\#BIBL

Medline items on this article's topics can be found at http://highwire.stanford.edu/lists/artbytopic.dtl on the following topics:

Oncology .. Hypoxia

Physiology .. Exertion

Physiology .. Cardiac Output

Medicine .. Anoxia

Medicine .. Fitness (Physical Activity)

Medicine .. Exercise

Updated information and services including high-resolution figures, can be found at:

http://jap.physiology.org/cgi/content/full/100/2/749

Additional material and information about Journal of Applied Physiology can be found at: http://www.the-aps.org/publications/jappl

This information is current as of May 4, 2006.

Journal of Applied Physiology publishes original papers that deal with diverse areas of research in applied physiology, especially those papers emphasizing adaptive and integrative mechanisms. It is published 12 times a year (monthly) by the American

Physiological Society, 9650 Rockville Pike, Bethesda MD 20814-3991. Copyright @ 2005 by the American Physiological Society. ISSN: 8750-7587, ESSN: 1522-1601. Visit our website at http://www.the-aps.org/. 
The following letter is in response to the Point:Counterpoint series "Positive effects of intermittent hypoxia (live high:train low) on exercise performance are/are not mediated primarily by augmented red cell volume" that appeared in the November 2005 issue (vol. 99: 2053-2058, 2005; http://jap.physiol.org/ content/vol99/issue5).

To the Editor: Excellent discussion (5). However, the evidence for $[\mathrm{Hb}]$ changes as being the main factor accounting for the effects of altitude training on performance is weak, because the increase in [Hb] (5-10\%) explained only $16 \%$ of the variance in the increase in $\dot{\mathrm{V}}_{2}$ max. In addition, the increase in $\dot{\mathrm{V}}_{2}$ max only minimally explained the variance of the improvement in performance. Moreover, the following facts deserve further attention. First, $[\mathrm{Hb}]$ increased by twice as much in the HiHi (live high:train high) than in the HiLo (live high:train low) groups, whereas the increase of $\dot{\mathrm{V}}_{2} \max$ was similar in both groups. Second, it is not clear why the HiHi group did not improve performance despite the increase of $\dot{\mathrm{V}}_{2}$ max and [Hb]. Third, some subjects appear to improve their $\dot{\mathrm{V}}_{2} \max$ more than accountable only by the increase in [Hb]. Fourth, blood transfusion studies show more marked effects on endurance (performance) than on $\dot{\mathrm{V}}_{2}$ max and report a reduction of submaximal exercise blood lactate concentration after transfusion. Altitude training appears not to have significant effects on submaximal blood lactate concentration (4). Fifth, isovolemic $(1,2)$ and hypervolemic $(3)$ changes in $[\mathrm{Hb}]$ are consistently counterbalanced by changes in cardiac output and skeletal muscle blood flow such that for a given $\mathrm{O}_{2}$ demand, $\mathrm{O}_{2}$ delivery is maintained constant, but only during submaximal exercise. In Levine et al. (4), cardiac output was not affected by the increase of $[\mathrm{Hb}]$ when running at 8 and $10 \mathrm{mph}(\sim 60$ and $76 \%$ of their posttraining $\dot{\mathrm{V}}_{2}$ max $)$, but it was reduced when running at $12 \mathrm{mph}(\sim 90 \%)$. Thus the discussion remains open.

\section{REFERENCES}

1. Calbet JA. Oxygen tension and content in the regulation of limb blood flow. Acta Physiol Scand 168: 465-472, 2000.

2. Calbet JA, Radegran G, Boushel R, Sondergaard H, Saltin B, and Wagner PD. Effect of blood haemoglobin concentration on $\dot{\mathrm{VO}}_{2}$ max and cardiovascular function in lowlanders acclimatised to $5260 \mathrm{~m}$. J Physiol 545: 715-728, 2002.

3. Calbet JA, Radegran G, Boushel R, Sondergaard H, Saltin B, and Wagner PD. Plasma volume expansion does not increase maximal cardiac output or $\mathrm{V}_{2}$ max in lowlanders acclimatized to altitude. Am J Physiol Heart Circ Physiol 287: H1214-H1224, 2004.

4. Levine BD and Stray-Gundersen J. "Living high-training low": effect of moderate-altitude acclimatization with low-altitude training on performance. J Appl Physiol 83: 102-112, 1997.

5. Levine BD and Stray-Gundersen J; Gore CJ and Hopkins WG. Point: Counterpoint: Positive effects of intermittent hypoxia (live high:train low) on exercise are/are not mediated primarily by augmented red cell volume. J Appl Physiol 99: 2053-2058, 2005.

José A L Calbet

Department of Physical Education University of Las Palmas de Gran Canaria Canary Islands, Spain; and

The Copenhagen Muscle Research Centre Rigshospitalet Copenhagen N, Denmark e-mail: jcalbet@def.ulpgc.es

Robert Boushel

Department of Exercise Science Concordia University

Montreal, Quebec, Canada

Carsten Lundby

Vetsuisse Faculty University of Zürich Institute of Veterinary Physiology Zürich, Switzerland 